University of Nebraska - Lincoln

DigitalCommons@University of Nebraska - Lincoln

1973

\title{
Ecological Distribution of Breeding Waterfowl Populations in North Dakota
}

\author{
Robert E. Stewart \\ USGS Northern Prairie Wildlife Research Center \\ Harold A. Kantrud \\ USGS Northern Prairie Wildlife Research Center
}

Follow this and additional works at: https://digitalcommons.unl.edu/usgsnpwrc

Part of the Other International and Area Studies Commons

Stewart, Robert E. and Kantrud, Harold A., "Ecological Distribution of Breeding Waterfowl Populations in North Dakota" (1973). USGS Northern Prairie Wildlife Research Center. 178.

https://digitalcommons.unl.edu/usgsnpwrc/178

This Article is brought to you for free and open access by the US Geological Survey at DigitalCommons@University of Nebraska - Lincoln. It has been accepted for inclusion in USGS Northern Prairie Wildlife Research Center by an authorized administrator of DigitalCommons@University of Nebraska - Lincoln. 


\title{
ECOLOGICAL DISTRIBUTION OF BREEDING WATERFOWL POPULATIONS IN NORTH DAKOTA
}

ROBERT E. STEWART, Northern Prairie Wildlife Research Center, Jamestown, North Dakota 58401

HAROLD A. KANTRUD, Northern Prairie Wildlife Research Center, Jamestown, North Dakota 58401

\begin{abstract}
The distribution of breeding waterfowl populations on various wetland habitat types was investigated in North Dakota during 1967-69. Data were obtained by stratified random sampling techniques. The total wetland acreage in North Dakota was estimated to be about 3.2 million acres. Natural basin wetlands comprised about 77 percent of the acreage and 91 percent of the number of wetlands in the state and were utilized by about 76 percent of the state's breeding duck population. Among the four biotic regions of the state, numerical and areal composition of wetlands varied considerably. Natural basin wetlands varied from a low of about 4 percent of total wetland acreage in the Southwestern Slope Region to a high of 93 percent in the Prairie Pothole Region. About 84 percent of the statewide duck population occurred in the Prairie Pothole Region. Within the Prairie Pothole Region, seasonal (Class III) ponds comprised 36 and 23 percent, respectively, of the total acreage and number of wetlands, and semipermanent (Class IV) ponds and lakes comprised 18 and 3 percent, respectively, of these totals. Agriculture has had drastic effects on the wetlands in this region as evidenced by the fact that natural basin wetlands with tilled bottom soils (chiefly Class II and Class III wetlands) comprised about 29 percent of area but 52 percent of numbers of all wetlands. In the Prairie Pothole Region, seasonal ponds and semipermanent ponds and lakes were utilized by about 48 and 27 percent, respectively, of the total breeding ducks. Optimum environmental conditions for breeding dabbling ducks were present during years when large numbers and acreages of seasonal (Class III) pond basins contained surface water. Semipermanent (Class IV) ponds and lakes were the principal habitats for breeding diving ducks, and were also important to dabbling ducks, particularly during dry years.
\end{abstract}

J. WILDL. MANAGE. 37(1):39-50

The paramount importance of the glaciated prairie region as a breeding ground for North American waterfowl has been well established. This region contains innumerable shallow wetlands with discrete basins that are especially attractive to various species of dabbling and diving ducks during the nesting season. Unfortunately, the natural ecosystems within this region have been drastically altered by intensive agricultural development during the past 75 years. Since these environmental changes are continuing at an unabated rate, it is essential that their impact on the distribution, population densities, and ecology of breeding waterfowl should be monitored.

The primary purpose of this report is to document the ecological distribution of populations of breeding waterfowl on prairie wetlands in North Dakota from 1967 through 1969 so as to provide a basis for evaluating effects of future environmental changes. The data are based on counts of breeding duck pairs on various types of wetland within sample units that were selected by stratified random sampling techniques. The sample units were distributed within strata that were differentiated by biogeographical, physiographical, and ecological factors (Stewart and Kantrud 1972).

The habitats included are the major classes of natural basin wetlands (Stewart and Kantrud 1971), fluviatile wetlands, and various man-made wetlands. The permanence of surface water in five classes of natural basin wetlands varies in degree and is correlated with differences in the vegetation of the central zones of the wetlands. These classes, listed in order of increasing permanence, are: ephemeral (Class I) ponds, temporary (Class II) ponds, sea- 


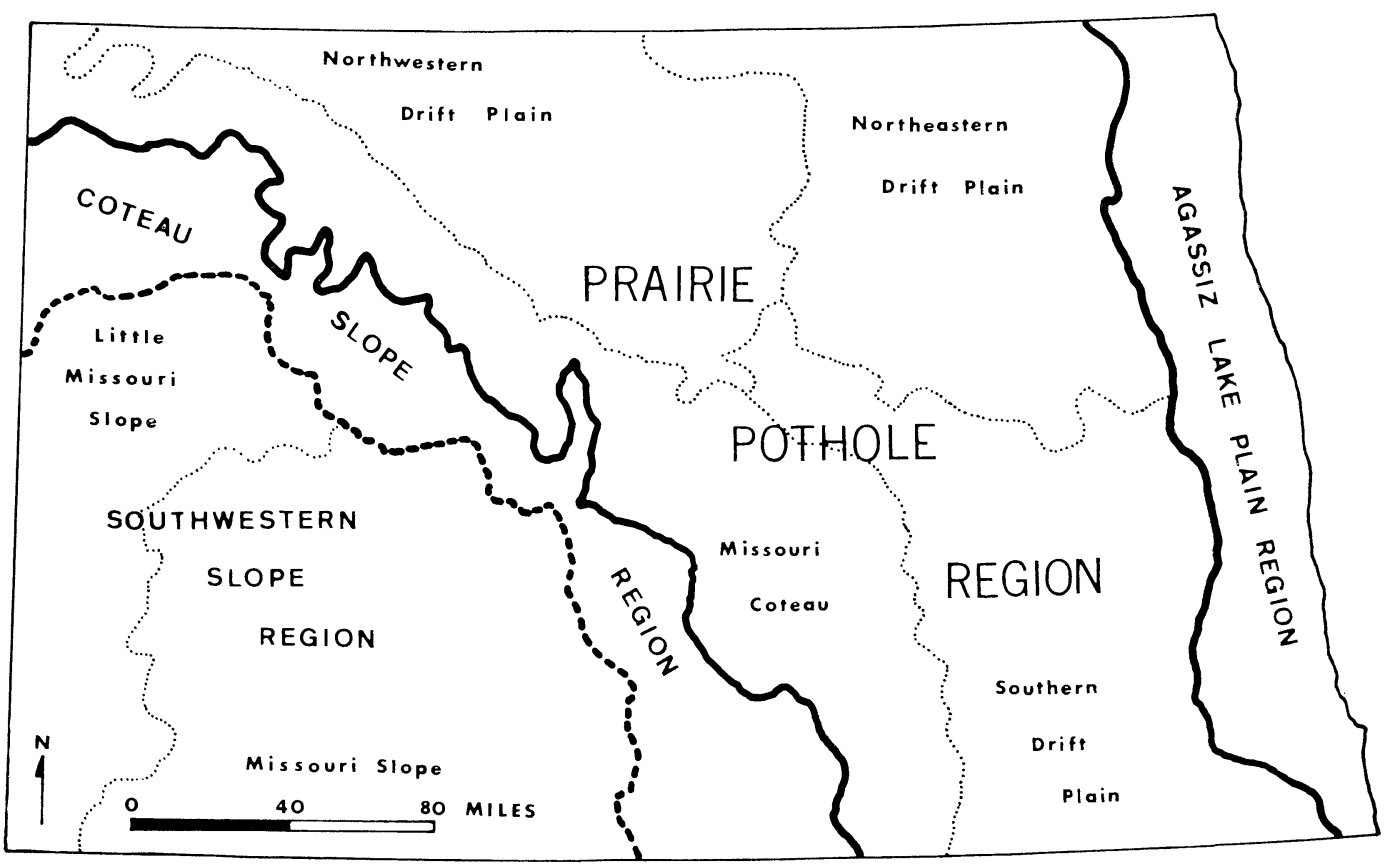

Fig. 1. Biotic regions and subregions of North Dakota.

sonal (Class III) ponds, semipermanent (Class IV) ponds and lakes, and permanent (Class V) ponds and lakes. In addition, alkali (Class VI) ponds and lakes are characterized by the intermittent occur-

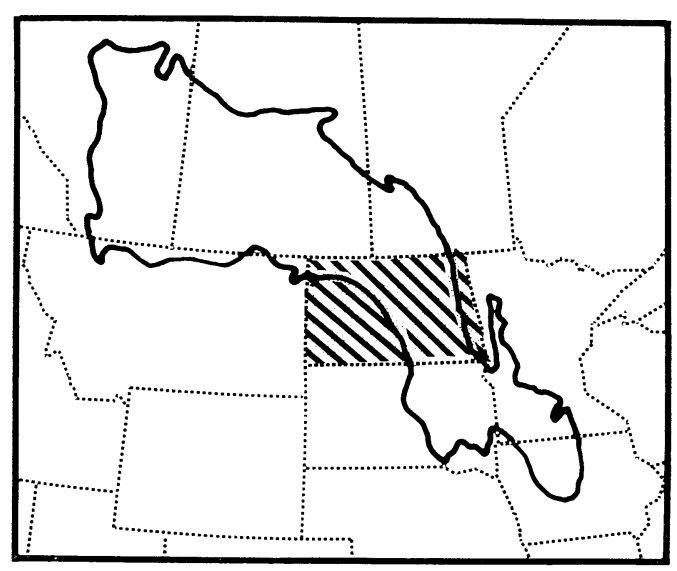

Fig. 2. Relationship of North Dakota to prairie pothole area of central North America. rence of shallow, highly saline surface water; and fen (Class VII) ponds represent basin wetlands in which alkaline ground water seeps to the surface. Fluviatile wetlands include permanent and intermittent streams and their associated oxbows. Manmade wetlands are represented by stock ponds, dugouts, large shallow stream impoundments, reservoirs, road ditches, drainage channels, and sewage lagoons.

We wish to thank D. Alan Davenport for developing computer programs to process the data from this study. Grateful acknowledgment is made to personnel ( 32 in number) from the U.S. Bureau of Sport Fisheries and Wildlife, U.S. Soil Conservation Service, and North Dakota Game and Fish Department for their assistance with waterfowl censuses during 1969. A special thanks also is due William C. Bair and Paul F. Springer for their help in coordinating work schedules of many of the biologists 
who participated in the field work that year.

\section{METHODS}

These investigations were statewide in 1967, but were restricted to the Prairie Pothole Region (Figs. 1 and 2) in 1968 and 1969. The field work in 1967 and 1968 was conducted by the authors without assistants. In 1969 , a cooperative program was instituted in which many federal and state biologists assisted in the census of waterfowl on various assigned portions of the region.

The criteria involved in the biotic stratification of the state, the random methods employed for selection of sample units, and the field techniques utilized in censusing waterfowl and other birds have been described previously (Stewart and Kantrud 1972).

During the waterfowl censuses, our interpretation of segregated pairs, lone males, and mixed flocks of both sexes was in general agreement with the guidelines established by Hammond (1969). Occasionally, we found that the number of lone females on a given sample unit exceeded the number of males unaccompanied by females. In such a case, each "excess" lone female was considered to represent an indicated pair. Flocks of male mallards (Anas platyrhynchos) or pintails (Anas acuta) containing as many as 10 individuals were sometimes observed during principal breeding periods. In these cases each male was considered to indicate a pair, as recommended by Dzubin (1969).

Censuses of all ducks were conducted each year during the principal breeding periods. The breeding period for each species differed slightly from year to year because of variable climatic conditions. Periods also varied considerably among the various waterfowl species. The mallard and pintail, both early-nesting species, were censused from 24 April to 7 June 1967, and from 23 April to 7 June 1968. Mid-nesting species, including the gadwall (Anas strepera), green-winged teal (Anas carolinensis), bluewinged teal (Anas discors), shoveler (Spatula clypeata), American widgeon (Mareca americana), ring-necked duck (Aythya collaris), and canvasback (Aythya valisineria), were censused from 14 May to 10 July 1967, and from 15 May to 15 July 1968. Latenesting species, including the redhead (Aythya americana), lesser scaup (Aythya affinis), and ruddy duck (Oxyura jamaicensis) were censused from 22 May to 19 July 1967, and from 20 May to 23 July 1968.

In 1969, because of the limited time available for cooperation in census work by other investigators, the censuses of all ducks were conducted during the overlapping portion of the principal breeding periods for early-nesting, mid-nesting, and latenesting species. This composite period extended from 20 May to 10 June.

The statewide sample of breeding habitat in 1967 consisted of 130 legal quarter sections ( 160 acres, or 0.5 mile $\times 0.5$ mile). The number of sample units allocated to each stratum was in proportion to its relative size. Sample units were distributed among the biotic regions and subregions of the state (Fig. 1) as follows: Agassiz Lake Plain-13; Northeastern Drift Plain-17; Southern Drift Plain-18; Northwestern Drift Plain-15; Missouri Coteau-18; Coteau Slope-15; Missouri Slope-21; and Little Missouri Slope-13.

Variance estimates (Cochran 1963), obtained from the data in 1967, were used as an aid to determine adequate sample size for the survey of the Prairie Pothole Region in 1968. Censuses of waterfowl were conducted on 194 randomly selected quarter sections. These included 81 located on the Missouri Coteau and 113 on the Drift Plain. 
Within the Drift Plain the number of sample units allocated to each biotic subdivision was in proportion to its size: 35 on the Northeastern Drift Plain, 42 on the Southern Drift Plain, and 36 on the Northwestern Drift Plain.

A cluster sampling technique was utilized in 1969 in an attempt to decrease the proportion of zero observations, thus reducing skewness and permitting more reliable estimates of waterfowl numbers. Each cluster consisted of four quarter sections that formed the corners of a square with dimensions of $2 \times 2$ miles. Because cooperating biologists were not always available, the degree of coverage differed considerably among the various subregions of the Prairie Pothole Region. Censuses were conducted on 83 clusters containing 332 quarter-section units. The clusters were randomly distributed among the four subregions of the Prairie Pothole Region (Fig. 1) as follows: 40 on the Missouri Coteau, 23 on the Southern Drift Plain, 10 on the Northeastern Drift Plain, and 10 on the Northwestern Drift Plain.

A survey of wetland habitat was completed in conjunction with the censuses of waterfowl on the sample units each year. Type and acreage of every wetland was determined. Acreages of most wetlands were estimated through visual appraisals and pacing although, in the case of large wetlands, topographic maps were used. If a portion of a wetland extended outside the boundary of a sample unit, only the acreage within the sample unit was recorded. Data for both wetlands and waterfowl were weighted in order to adjust for differences in density of sample units.

\section{RESULTS}

\section{Waterfowl Breeding Populations}

In 1967, the census of ducks on 130 randomly selected quarter-section sample units throughout the state yielded a total of 1,037 breeding pairs. On the basis of strata mean densities the total waterfowl breeding population for North Dakota was estimated to be $2,281,000$ pairs with a 95 percent Highest Probability Density (HPD) region of $1,703,000$ to $2,859,000$ pairs (Stewart and Kantrud 1972).

Breeding waterfowl populations were of regular occurrence in the four major biotic regions in North Dakota. These are designated as the Agassiz Lake Plain Region, the Prairie Pothole Region, the Coteau Slope Region, and the Southwestern Slope Region (Fig. 1). Census data from the 1967 statewide study clearly show that breeding populations were largely concentrated in the Prairie Pothole Region. About 84 percent of the total breeding pairs were found in this region which covers 51.5 percent of the state area. Elsewhere, about 10 percent of the total population occurred in the Coteau Slope Region (11.6 percent of the state area), 4 percent in the Southwestern Slope Region (26.9 percent of the state area), and only 2 percent in the Agassiz Lake Plain Region (10.0 percent of the state area).

Breeding duck populations in the Prairie Pothole Region of North Dakota often fluctuate considerably from year to year due to the extreme variations in climate characterizing the northern glaciated prairies. These variations cause pronounced differences in water conditions of the prairie wetlands. Based on the 1967 study and on the similar, more intensive random-sampling studies in 1968 and 1969, the breeding duck populations in the Prairie Pothole Region were estimated as follows:

$$
\begin{aligned}
& 1967-1,907,000 \text { pairs ( } 95 \text { percent HPD } \\
& \text { region of } 1,346,000-2,467,000 \text { pairs). } \\
& 1968 \text { - } 995,000 \text { pairs ( } 95 \text { percent HPD } \\
& \text { region of } 769,000-1,222,000 \text { pairs). }
\end{aligned}
$$


1969—1,955,000 pairs (95 percent HPD region of $1,621,000-2,289,000$ pairs ).

The 3-year average population for this region approximated about $1,600,000$ pairs.

Yearly fluctuations in populations of breeding waterfowl shown by our data compared favorably with indices to populations recently compiled from adjusted aerial survey data by the Bureau of Sport Fisheries and Wildlife (Pospichal et al. 1972). In these surveys, population indices of $1,559,000,870,000$, and 1,670,000 breeding pairs within the Prairie Pothole Region were calculated for 1967, 1968, and 1969, respectively. Statewide indices compiled by Schroeder (1971) from roadside transect data also showed similar yearly population fluctuations during this period.

\section{Composition of Wetlands}

The total wetland acreage in North Dakota was estimated to be about 3.2 million acres, based on data derived from the 130 randomly selected sample units in 1967 . Natural basin wetlands and "other wetlands" comprised about 2.5 and 0.7 million acres, respectively. A large proportion of the acreage of "other wetlands" was composed of reservoirs and large impoundments. The total number of natural basin wetlands and "other wetlands" was estimated to be about 2.7 and 0.3 million units, respectively. Road ditches and drainage channels were the most numerous types of "other wetlands."

Bach (1951) reported about 1,014,000 depressions, in North Dakota, capable of holding water. $\mathrm{He}$ estimated that these depressions would contain approximately $3,000,000$ acres of surface water during an extremely wet year. According to the North Dakota State Water Commission (North Dakota State Water Comm. Rep. 1968), about 485,000 acres of reservoirs and im- poundments over 50 acres in size occurred in the state.

Percentages of wetland habitats by areas and numbers are shown in Table 1 for each of the major biotic regions and for the state as a whole. Over 90 percent of the wetland area in the Prairie Pothole and Agassiz Lake Plain Regions was composed of natural basin wetlands. Reservoirs and large impoundments made up the largest area of wetlands in the Coteau Slope Region. In the Southwestern Slope Region the only extensive areas of wetlands were dugouts, stock ponds, oxbows, and streams.

Throughout the greater part of the state, the numerical composition of wetland habitat was less variable than the areal composition. Natural basin wetlands comprised 83 percent or more of the total number of wetlands in the Agassiz Lake Plain, Prairie Pothole, and Coteau Slope Regions. However, they accounted for only 15 percent of the wetlands in the Southwestern Slope Region. In the last region, 85 percent of the total number of wetlands was represented by streams, oxbows, and various man-made wetlands, including stock ponds, dugouts, and road ditches.

The Prairie Pothole Region (Fig. 1) contained an estimated 2.2 million acres of wetlands, projected from data on 68 randomly selected sample units in 1967. Natural basin wetlands and "other wetlands" comprised about 2.0 and 0.2 million acres, respectively. The detailed composition of wetland habitats in the Prairie Pothole Region is expressed in terms of proportional areas and proportional numbers of specific habitat types (Table 2). A survey of small wetlands in the Prairie Pothole and Coteau Slope Regions (Unpublished report, 1964, North Dakota Wetland Inventory, Bureau of Sport Fisheries and Wildlife) revealed approximately 317,000 wetlands which contained about $1,468,000$ acres. This 
Table 1. Generalized composition of wetland habitat types in major biotic regions of North Dakota, 1967.

\begin{tabular}{|c|c|c|c|c|c|c|c|c|c|c|}
\hline \multirow[b]{3}{*}{ Habitat Type } & \multicolumn{5}{|c|}{ Percent of Wetland Acreagea } & \multicolumn{5}{|c|}{ Percent of Numbers b } \\
\hline & \multicolumn{4}{|c|}{ Region } & \multirow[b]{2}{*}{$\begin{array}{l}\text { State- } \\
\text { wide }\end{array}$} & \multicolumn{4}{|c|}{ Region } & \multirow[b]{2}{*}{$\begin{array}{l}\text { State- } \\
\text { wide }\end{array}$} \\
\hline & $\begin{array}{c}\text { Agassiz } \\
\text { Lake } \\
\text { Plain }\end{array}$ & $\begin{array}{l}\text { Prairie } \\
\text { Pothole }\end{array}$ & $\begin{array}{l}\text { Coteau } \\
\text { Slope }\end{array}$ & $\begin{array}{c}\text { South- } \\
\text { western } \\
\text { Slope }\end{array}$ & & $\begin{array}{l}\text { Agassiz } \\
\text { Lake } \\
\text { Plain }\end{array}$ & $\begin{array}{c}\text { Prairie } \\
\text { Pothole }\end{array}$ & $\begin{array}{l}\text { Coteau } \\
\text { Slope }\end{array}$ & $\begin{array}{c}\text { South- } \\
\text { western } \\
\text { Slope }\end{array}$ & \\
\hline Natural basin wetlands & 92 & 93 & 16 & 4 & 76 & 86 & 94 & 83 & 15 & 91 \\
\hline Streams and oxbows & 3 & 5 & 6 & 41 & 5 & 1 & 1 & 7 & 35 & 2 \\
\hline Stock ponds and dugouts & $\mathrm{T}^{\mathrm{c}}$ & $\mathrm{T}^{\mathrm{c}}$ & 3 & 54 & 2 & $\mathrm{~T}^{\mathrm{c}}$ & 1 & 4 & 26 & 1 \\
\hline Reservoirs and & & & & & & & & & & \\
\hline large impoundments & $\mathrm{T}^{\mathrm{c}}$ & 2 & 74 & $T^{\mathrm{c}}$ & 15 & $\mathrm{~T}^{\mathrm{e}}$ & $\mathrm{T}^{\mathrm{c}}$ & $\mathrm{T}^{\mathrm{c}}$ & $\mathrm{T}^{\mathrm{c}}$ & $\mathrm{T}^{\mathrm{c}}$ \\
\hline Road ditches and & & & & & & & & & & \\
\hline drainage channels & 6 & $\mathrm{~T}^{\mathrm{c}}$ & $\mathrm{T}^{\mathrm{c}}$ & 1 & 1 & 13 & 4 & 6 & 24 & 5 \\
\hline Other (sewage lagoons etc.) & $\mathrm{T}^{\mathrm{c}}$ & $\mathrm{T}^{\mathrm{c}}$ & $\mathrm{T}^{\mathrm{c}}$ & $\mathrm{T}^{\mathrm{c}}$ & $\mathrm{T}^{\mathbf{e}}$ & $\mathrm{T}^{\mathrm{c}}$ & $\mathrm{T}^{\mathrm{c}}$ & $\mathrm{T}^{\mathrm{e}}$ & $\mathrm{T}^{\mathrm{c}}$ & $\mathrm{T}^{\mathrm{c}}$ \\
\hline Total & 100 & 100 & 100 & 100 & 100 & 100 & 100 & 100 & 100 & 100 \\
\hline
\end{tabular}

^ Areas with or without surface water.

b Includes wetlands lying partially inside quarter-section boundaries.

c $\mathrm{T}$ indicates 0.5 percent or less.

survey was based on interpretation of aerial photographs and, of necessity, excluded the more temporary wetland types.

In the Prairie Pothole Region, natural basin wetlands with untilled bottom soils occupied the largest area among the wetlands (63 percent), and comprised 42 percent of total numbers of wetlands. Seasonal (Class III) ponds and semipermanent (Class IV) ponds and lakes were the prevalent types of basin wetlands with untilled bottom soils. In combination they accounted for 51 percent of the total area of all wetlands. The drastic effect of agriculture on this region is shown by the comparison: wetlands with tilled bottom soils comprised 29 percent of the area but represented 52 percent of the total number of all wetlands.

\section{Generalized Distribution of Breeding Waterfowl by Habitat}

Breeding waterfowl in North Dakota are especially characteristic of four generalized categories of wetland habitat: (1) natural ponds and lakes, (2) streams and oxbows, (3) stock ponds and dugouts, and (4) reservoirs and large impoundments. In
1967, 76 percent of the breeding ducks in the state were found on natural ponds and lakes, 9 percent on reservoirs and large impoundments, 8 percent on streams and oxbows, and 5 percent on stock ponds and dugouts (Table 3 ). Miscellaneous habitats including road ditches, drainage channels, sewage lagoons, and various types of upland habitat were occupied by 2 percent of the breeding pairs.

The distribution of breeding ducks varied markedly in the generalized habitat types of the state (Table 3). Natural ponds and lakes were of paramount importance to breeding ducks in the Agassiz Lake Plain Region, Prairie Pothole Region, and Coteau Slope Region, but were of negligible importance in the Southwestern Slope Region. In contrast, the greater proportion of breeding ducks in the Southwestern Slope Region were found on stock ponds and dugouts. These man-made, stock-watering wetlands also were used to a considerable extent in in the Coteau Slope Region, but were of little importance elsewhere. The relative use of the other wetland categories was quite variable, although, in general, they could be considered of minor significance. 
Table 2. Detailed composition of wetland habitat types in the Prairie Pothole Region of North Dakota, 1967.

\begin{tabular}{|c|c|c|}
\hline Habitat Type & $\begin{array}{c}\text { PERCENT of } \\
\text { WetLAND ACREAGE }\end{array}$ & $\begin{array}{c}\text { PERCENT of } \\
\text { NuMBER }\end{array}$ \\
\hline \multicolumn{3}{|l|}{ Natural wetlands } \\
\hline \multicolumn{3}{|l|}{ Basin wetlands } \\
\hline \multicolumn{3}{|l|}{ Prairie ponds and lakes (with untilled bottom soils) } \\
\hline Ephemeral ponds (Class I) & 1 & 9 \\
\hline Temporary ponds (Class II) & 2 & 9 \\
\hline Seasonal ponds (Class III) & 33 & 21 \\
\hline Semipermanent ponds and lakes (Class IV) & 18 & 3 \\
\hline Permanent ponds and lakes (Class V) & 3 & $\mathrm{~T}^{\mathrm{a}}$ \\
\hline Alkali ponds and lakes (Class VI) & 6 & $\mathrm{~T}^{\mathrm{a}}$ \\
\hline Fen ponds (Class VII) & $\mathrm{T}^{\mathrm{a}}$ & $\mathrm{T}^{\mathrm{a}}$ \\
\hline \multicolumn{3}{|l|}{ Cropland ponds (with tilled bottom soils) } \\
\hline Temporary ponds (Class II) & 1 & 2 \\
\hline Seasonal ponds (Class III) & 3 & 2 \\
\hline Undifferentiated tillage ponds (Class II and III) & 25 & 48 \\
\hline Streams and oxbows & 5 & 1 \\
\hline \multicolumn{3}{|l|}{ Man-made wetlands } \\
\hline Stock ponds & $\mathrm{T}^{\mathrm{a}}$ & $\mathrm{T}^{\mathrm{a}}$ \\
\hline Dugouts & $\mathrm{T}^{2}$ & $\mathrm{~T}^{\mathrm{a}}$ \\
\hline Reservoirs and large impoundments & 2 & $\mathrm{~T}^{\mathrm{a}}$ \\
\hline Road ditches and drainage channels & $\mathrm{T}^{\mathbf{a}}$ & 4 \\
\hline Other (sewage lagoons etc.) & $\mathrm{T}^{\mathrm{a}}$ & $\mathrm{T}^{\mathrm{a}}$ \\
\hline Total & 100 & 100 \\
\hline
\end{tabular}

${ }^{a} \mathrm{~T}$ indicates 0.5 percent or less.

\section{Ecological Distribution of Waterfowl in the Prairie Pothole Region}

The distribution of breeding waterfowl in specific wetland habitat types within the Prairie Pothole Region of North Dakota is shown in Table 4. These data, accumulated over a 3-year period (1967-69), afford an opportunity to establish relative values to waterfowl for the major classes of natural basin wetlands that were described by Stewart and Kantrud (1971). In addition, the relative values of streams and oxbows, and various types of man-made wetlands may be assessed.

On the basis of the average distribution

Table 3. Ecological distribution (percent) of total breeding duck populations in major biotic regions of North Dakota, 1967.

\begin{tabular}{|c|c|c|c|c|c|}
\hline \multirow[b]{2}{*}{ Habitat Type } & \multicolumn{4}{|c|}{ REgION } & \multirow[b]{2}{*}{$\begin{array}{c}\text { STATEWIDE } \\
(N=1,037 \\
\text { pairs })\end{array}$} \\
\hline & $\begin{array}{c}\text { Agassiz Lake } \\
\text { Plain } \\
(N=17 \\
\text { pairs })\end{array}$ & $\begin{array}{c}\text { Prairie } \\
\text { Pothole } \\
(N=872 \\
\text { pairs })\end{array}$ & $\begin{array}{c}\text { Coteau } \\
\text { Slope } \\
(N=106 \\
\text { pairs })\end{array}$ & $\begin{array}{c}\text { Southwestern } \\
\text { Slope } \\
(N=42 \\
\text { pairs })\end{array}$ & \\
\hline Natural ponds and lakes & 88 & 80 & 70 & 0 & 76 \\
\hline Streams and oxbows & 6 & 8 & 13 & 5 & 8 \\
\hline Stock ponds and dugouts & 0 & $\mathrm{~T}^{\mathrm{a}}$ & 17 & 83 & 5 \\
\hline Reservoirs and large impoundments & 0 & 11 & 0 & 0 & 9 \\
\hline Road ditches and drainage channels & 6 & 2 & 0 & 5 & 2 \\
\hline Other habitats & 0 & $\mathrm{~T}^{\mathrm{a}}$ & 0 & 7 & $\mathrm{~T}^{\mathrm{a}}$ \\
\hline Total & 100 & 100 & 100 & 100 & 100 \\
\hline
\end{tabular}

a Indicates 0.5 percent or less.

b Mostly dry habitats on the upland. 
Table 4. Ecological distribution of breeding duck populations in the Prairie Pothole Region of North Dakota.

\begin{tabular}{|c|c|c|c|c|}
\hline \multirow[b]{2}{*}{ HaBItat Type } & \multicolumn{3}{|c|}{ PERCENT OF } & \multirow{2}{*}{$\begin{array}{l}\text { PERCENT T } \\
\text { AVERAGE } \\
1997-69\end{array}$} \\
\hline & $\begin{array}{l}872 \text { Pairs } \\
\text { in } 1967\end{array}$ & $\begin{array}{l}1,529 \text { Pairs } \\
\text { in } 1968\end{array}$ & $\begin{array}{l}4,790 \text { Pairs } \\
\text { in } 1969\end{array}$ & \\
\hline \multicolumn{5}{|l|}{ Natural wetlands } \\
\hline \multirow{2}{*}{\multicolumn{5}{|c|}{$\begin{array}{l}\text { Basin wetlands } \\
\text { Prairie ponds and lakes (with untilled bottom soils) }\end{array}$}} \\
\hline & & & & \\
\hline Ephemeral ponds (Class I) & $\mathrm{T}^{\mathrm{a}}$ & $\mathrm{T}^{\mathrm{a}}$ & 0 & $\mathrm{~T}^{\mathrm{a}}$ \\
\hline Temporary ponds (Class II) & 2 & 1 & 2 & 1 \\
\hline Seasonal ponds (Class III) & 50 & 32 & 45 & 42 \\
\hline Semipermanent ponds and lakes (Class IV) & 16 & 41 & 23 & 27 \\
\hline Permanent ponds and lakes (Class V) & 0 & 8 & 1 & 3 \\
\hline Alkali ponds and lakes (Class VI) & 1 & $\mathrm{~T}^{\mathrm{a}}$ & $\mathrm{T}^{\mathrm{a}}$ & $\mathrm{T}^{\mathrm{a}}$ \\
\hline Fen ponds (Class VII) & 0 & $\mathrm{~T}^{\mathrm{a}}$ & $\mathrm{T}^{\mathrm{a}}$ & $\mathrm{T}^{\mathrm{a}}$ \\
\hline \multicolumn{5}{|l|}{ Cropland ponds (with tilled bottom soils) } \\
\hline Temporary ponds (Class II) & 0 & 1 & 2 & 1 \\
\hline Seasonal ponds (Class III) & 3 & 3 & 9 & 5 \\
\hline Undifferentiated tillage ponds (Class II and III) & 8 & 2 & 6 & 5 \\
\hline Streams and oxbows & 7 & 5 & 4 & 6 \\
\hline \multicolumn{5}{|l|}{ Man-made wetlands } \\
\hline Stock ponds & $\mathrm{T}^{\mathbf{a}}$ & 2 & 1 & 1 \\
\hline Dugouts & 0 & 2 & 2 & 1 \\
\hline Reservoirs and large impoundments & 11 & 0 & 3 & 4 \\
\hline Road ditches and drainage channels & 2 & 1 & 1 & 2 \\
\hline Other (sewage lagoons etc.) & 0 & $\mathrm{~T}^{\mathrm{a}}$ & 0 & $\mathrm{~T}^{2}$ \\
\hline Upland habitats & $\mathrm{T}^{2}$ & $\mathrm{~T}^{a}$ & 1 & $\mathrm{~T}^{\mathrm{a}}$ \\
\hline Total & 100 & 100 & 100 & 100 \\
\hline
\end{tabular}

a Indicates 0.5 percent or less.

during the period $1967-69$, about 84 percent of the breeding ducks were found on natural basin wetlands. The relationship to agricultural land-use practices is shown by the fact that 73 percent of the total population was found on natural basin wetlands with untilled bottom soils, and 11 percent on wetlands with tilled basins in cropland.

It is apparent that seasonal (Class III) ponds and semipermanent (Class IV) ponds and lakes represent the primary wetland habitats for breeding waterfowl. An average (1967-69) of about three-fourths of the breeding ducks used these two wetland classes, including seasonal ponds with tilled bottom soils.

Use of other wetlands was much more limited. However, streams and oxbows, reservoirs and large impoundments were of appreciable value to breeding ducks for they were occupied by 6 percent and 4 percent of the total number, respectively. Many wetland habitats of low value were used by proportions of the population ranging from 1 to 3 percent. These included temporary (Class II) ponds, permanent (Class V) ponds and lakes, stock ponds, dugouts, road ditches, and drainage channels. Other wetland habitats were inconsequential to breeding waterfowl since they were each occupied by less than 0.5 percent of the waterfowl population. These included ephemeral (Class I) ponds, alkali (Class VI) ponds and lakes, fen (Class VII) ponds, and sewage lagoons.

Noticeable yearly fluctuations in the ecological distribution of breeding waterfowl frequently occur in the Prairie Pothole Region (Table 4) due primarily to changing climatic conditions. These differences are closely related to yearly variations in the acreage of seasonal ponds with surface 
water. During the waterfowl breeding seasons of 1967 and 1969, excellent water conditions prevailed in the Prairie Pothole Region, while in 1968, there was a fairly severe drought over a large portion of the area. In 1967 and 1969 (Table 4), seasonal ponds (including those with tilled bottom soils) were used, respectively, by 53 percent and 54 percent of the breeding ducks while semipermanent ponds and lakes were used by only 16 percent and 23 percent of the ducks. During these 2 years, the average acreage of seasonal ponds with surface water per sample unit was 4.74 and 5.37, respectively. In 1968, seasonal ponds were used by 35 percent of the breeding ducks and semipermanent ponds and lakes by 41 percent. At this time, the average acreage of seasonal ponds with surface water was down to 1.78 per sample unit.

These findings are in agreement with data presented by Stoudt (1971) from detailed investigations of waterfowl habitat in the prairie parklands of Saskatchewan. His report indicates that a much larger proportion of the total breeding duck population occurred on less permanent wetland types during years when maximum acreages of wetland basins contained surface water. The situation in the prairie pothole region of Minnesota apparently is somewhat different. Studies in that area by Jessen et al. (1964) on a natural wetland complex containing a variety of wetland classes, indicated that the greater proportion of the breeding duck populations occurred on the more permanent types of basin wetlands each year regardless of water conditions.

\section{Ecological Distribution of Waterfowl Species}

The ecological distribution of breeding populations of the various species of waterfowl in the Prairie Pothole Region is detailed in Table 5. The proportions (in per- cent) of these populations that occurred in major habitat types or combination of types were based on a 3-year average of data obtained from the random-sampling studies of 1967, 1968, and 1969.

Certain generalized similarities in distribution are apparent among the species. Natural seasonal (Class III) ponds, and semipermanent (Class IV) ponds and lakes were found to be the primary wetland habitats utilized by all species for breeding. As few as 59 percent of the pintails and as many as 86 percent of the canvasbacks used these two habitats.

The proportional use of these two habitats (Class III and Class IV wetlands) by the two distinct ecological groups of species -dabblers and divers-differed markedly. Dabblers were represented on the sample areas chiefly by the mallard, gadwall, pintail, green-winged teal, blue-winged teal, shoveler, and American widgeon; divers, by the redhead, ring-necked duck, canvasback, lesser scaup, and ruddy duck. From 40 to 54 percent of populations of the principal species of dabbling ducks occupied natural seasonal ponds, but only 9 to 19 percent of populations of the diving duck species were found on them. Conversely, semipermanent ponds and lakes provided breeding habitat for 53 to 71 percent of populations of the principal species of diving ducks, but for only 12 to 32 percent of populations of the principal species of dabbling ducks.

Among the dabbling duck species, pintails were unique, for the proportion of the population occurring on cropland ponds (those with tilled bottom soils) was noticeably higher than for other species. Also, there were relatively high proportions of green-winged and blue-winged teals on seasonal ponds; of shovelers and gadwalls 
Table 5. Ecological distribution of breeding populations of waterfowl species in the Prairie Pothole Region of North Dakota.

\begin{tabular}{|c|c|c|c|c|c|c|c|c|c|}
\hline \multirow[b]{2}{*}{ SPECIES } & \multirow[b]{2}{*}{$\begin{array}{c}\text { Total } \\
\text { NuMBeR of } \\
\text { PAIRS IN } \\
\text { SAMPLE }\end{array}$} & \multicolumn{8}{|c|}{ Pencent Distribution (3-year average, 1967-69) } \\
\hline & & $\begin{array}{l}\text { Cropland } \\
\text { Ponds } \\
\text { (Class II }^{\text {\& III) }}\end{array}$ & $\begin{array}{c}\text { Prairie } \\
\text { Seasonal } \\
\text { Ponds } \\
\text { (Class III) }\end{array}$ & $\begin{array}{c}\text { Semiper- } \\
\text { manent } \\
\text { Ponds \& } \\
\text { Lakes } \\
\text { (Class IV) }\end{array}$ & $\begin{array}{l}\text { Other } \\
\text { Basin } \\
\text { Wet- } \\
\text { lands }\end{array}$ & $\begin{array}{c}\text { Streams } \\
\& \text { Ox- } \\
\text { bows }\end{array}$ & $\begin{array}{l}\text { Reservoirs } \\
\text { \& Large } \\
\text { Impound- } \\
\text { ments }\end{array}$ & $\begin{array}{c}\text { Other } \\
\text { Habi- } \\
\text { tats }^{\mathrm{c}}\end{array}$ & Total \\
\hline \multicolumn{10}{|l|}{ Dabbling ducks } \\
\hline Mallard & 934 & 15 & 44 & 20 & 4 & 8 & 2 & 6 & 100 \\
\hline Gadwall & 849 & 11 & 41 & 26 & 5 & 5 & 8 & 4 & 100 \\
\hline Pintail & 1,129 & 24 & 40 & 19 & 4 & 5 & 1 & 6 & 100 \\
\hline Green-winged teal & 247 & 12 & 54 & 12 & 8 & 3 & 4 & 6 & 100 \\
\hline Blue-winged teal & 2,322 & 8 & 52 & 24 & 4 & 5 & 3 & 4 & 100 \\
\hline Shoveler & 687 & 9 & 40 & 32 & 2 & 8 & 6 & 4 & 100 \\
\hline American widgeon & 107 & 12 & 42 & 18 & 3 & 8 & 11 & 5 & 100 \\
\hline \multicolumn{10}{|l|}{ Diving ducks } \\
\hline Redhead & 354 & 2 & 19 & 63 & 1 & 6 & 8 & $\mathrm{~T}^{\mathrm{d}}$ & 100 \\
\hline Ring-necked duck & 35 & 3 & 15 & 69 & 6 & 3 & 3 & 0 & 100 \\
\hline Canvasback & 107 & 1 & 15 & 71 & 1 & 0 & 10 & 2 & 100 \\
\hline Lesser scaup & 102 & 2 & 12 & 53 & 1 & 1 & 8 & $2 \overline{3}$ & 100 \\
\hline Ruddy duck & 315 & $\mathrm{~T}^{\mathrm{d}}$ & 9 & 67 & 12 & $\mathrm{~T}^{\mathrm{d}}$ & 12 & $\mathrm{~T}^{\mathrm{d}}$ & 100 \\
\hline
\end{tabular}

a Ponds with tilled bottom soils, including temporary (Class II) and seasonal (Class III) ponds.

b Ephemeral (Class I) ponds, permanent (Class V) ponds and lakes, alkali (Class VI) ponds and lakes, fen (Class (VII) ponds, and natural temporary (Class II) ponds (those with untilled bottom soils).

c Road ditches, drainage channels, sewage lagoons, stock ponds, dugouts, and upland habitats.

d Indicates less than $\mathbf{0 . 5}$ percent.

on semipermanent ponds; and of American widgeons on reservoirs and large impoundments. The ecological distribution of breeding populations of the more common species of dabbling ducks on the Waubay study area in northeastern South Dakota apparently is quite different. According to Drewien and Springer (1969), the proportion of dabbling ducks on semipermanent ponds and lakes was much greater than the proportion on seasonal ponds; however, this area contained a much higher proportion of semipermanent ponds than did North Dakota.

Among the species of diving ducks, the lesser scaup was found to be rather distinctive; the proportion of the population on semipermanent ponds was relatively low, while the proportion of its population on "other habitats," chiefly stock ponds and dugouts, was quite high.

\section{Local Variation in Ecological Distribution of Waterfowl}

Local variations in habitat use by breeding waterfowl populations were conspicuous in some areas, especially among the four biotic subregions or strata within the Prairie Pothole Region (Fig. 1). The distribution of all waterfowl populations in the principal wetland habitats or composite habitats is shown for each subregion in Table 6.

Seasonal and semipermanent ponds and lakes were important in all four subregions, although their relative use varied considerably. Seasonal ponds were used more extensively on the Northeastern Drift Plain and on the Missouri Coteau than elsewhere. The Missouri Coteau also was distinctive in that a much greater proportion ( 40 percent) of the breeding ducks occupied semipermanent ponds and lakes. The use of cropland ponds (those with tilled bottom soils) was especially pronounced on the 
Table 6. Variation in ecological distribution of breeding duck populations in the Prairie Pothole Region.

\begin{tabular}{|c|c|c|c|c|}
\hline \multirow[b]{3}{*}{ WetLand Habitats } & \multicolumn{4}{|c|}{ Percent Distribution (3-year average, 1967-69) } \\
\hline & \multicolumn{4}{|c|}{ Subregions } \\
\hline & $\begin{array}{c}\text { Northeastern } \\
\text { Drift Plain } \\
(N=911 \\
\text { pairs })\end{array}$ & $\begin{array}{c}\text { Southern } \\
\text { Drift Plain } \\
(N=1,615 \\
\text { pairs })\end{array}$ & $\begin{array}{c}\text { Northwestern } \\
\text { Drift Plain } \\
(N=717 \\
\text { pairs })\end{array}$ & $\begin{array}{c}\begin{array}{c}\text { Missouri } \\
\text { Coteau } \\
(N=3,948 \\
\text { pairs })\end{array} \\
\text { (n) }\end{array}$ \\
\hline Cropland ponds (Class II and III $)^{a}$ & 7 & 16 & 20 & 4 \\
\hline Prairie seasonal ponds (Class III) & 55 & 39 & 22 & 46 \\
\hline Semipermanent ponds and lakes (Class IV) & 21 & 27 & 17 & 40 \\
\hline Other basin wetlands & 1 & 8 & 4 & 2 \\
\hline Streams and oxbows & 8 & 4 & 16 & $\mathrm{~T}^{\mathrm{d}}$ \\
\hline Reservoirs and large impoundments & 4 & $\mathrm{~T}^{\mathrm{d}}$ & 18 & 3 \\
\hline Other habitats ${ }^{\mathrm{c}}$ & 5 & 5 & 4 & 4 \\
\hline Total & 100 & 100 & 100 & 100 \\
\hline
\end{tabular}

a Ponds with tilled bottom soils, including temporary (Class II) and seasonal (Class III) ponds.

b Ephemeral (Class I) ponds, permanent (Class V) ponds and lakes, alkali (Class VI) ponds and lakes, fen (Class VII) ponds, and natural temporary (Class II) ponds (those with untilled bottom soils).

c Road ditches, drainage channels, sewage lagoons, stock ponds, dugouts, and upland habitats.

a Indicates 0.5 percent or less.

Northwestern Drift Plain and Southern Drift Plain. Streams and oxbows, reservoirs, and large impoundments on the Northwestern Drift Plain were occupied by 34 percent of all the breeding ducks, a proportion much greater than for the other subregions.

\section{DISCUSSION}

The maintenance of populations of breeding waterfowl in North Dakota is dependent, in part, on the diversity of existing wetland habitats. Natural seasonal (Class III) ponds (those with untilled bottom soils) and semipermanent (Class IV) ponds and lakes are the primary wetland habitats used by waterfowl. Other wetland types that are fairly important to waterfowl include streams and oxbows, and wetlands with tilled basins in croplands. The latter group is especially attractive to pintails.

Other types of wetlands, including manmade ones, are responsible for maintaining certain local, rather limited, breeding populations. Stock ponds and dugouts serve this purpose in the Southwestern Slope Region, and are of appreciable importance also in the Coteau Slope Region. Along some of the river systems, waterfowl are benefited to some extent by reservoirs and large impoundments. At the J. Clark Salyer National Wildlife Refuge, shallow impoundments of the Mouse River are managed specifically for waterfowl through carefully regulated control of water levels. As a result, thousands of pairs of breeding ducks are attracted to this refuge each year.

Within the Prairie Pothole Region, small numbers of breeding waterfowl are found on temporary (Class II) ponds, and permanent (Class V) ponds and lakes. Several minor wetland types within this region are of proportionally little significance to the breeding waterfowl. These include ephemeral (Class I) ponds, alkali (Class VI) ponds and lakes, fen (Class VII) ponds, and sewage lagoons.

Optimum environmental conditions for breeding dabbling ducks apparently exist during years when large numbers and acreages of seasonal (Class III) pond basins contain surface water. The response of dabbling ducks to these conditions is indicated by the higher population densities in the principal waterfowl breeding area, the Prairie Pothole Region, and by the 
increased proportion of dabbling ducks using seasonal ponds. The number and acreage of seasonal pond basins with surface water are greatly reduced during years of low precipitation. These conditions are reflected in much lower densities of dabbling ducks and in lower proportions of dabbling ducks that utilize seasonal ponds.

Semipermanent (Class IV) ponds and lakes are the principal habitats for diving duck populations each year regardless of variations in general water conditions of total wetlands. They are of critical importance also to dabbling ducks, particularly during years of low precipitation when most basins of other wetland types are dry. The maintenance of a reserve stock of breeding dabbling ducks during these unfavorable periods is assured by the presence of semipermanent ponds and lakes and by the limited numbers and acreage of other, more permanent wetland types.

\section{LITERATURE CITED}

BACH, R. N. 1951. Some aspects of North Dakota's surface water. North Dakota State Game and Fish Dept. 13pp. Mimeogr.

Cochran, W. G. 1963. Sampling techniques. John Wiley and Sons, Inc. New York. 413pp.

Drewien, R. C., AND P. F. SPRINGer. 1969. Ecological relationships of breeding bluewinged teal to prairie potholes. Pages 102115 in Saskatoon wetlands seminar. Can. Wildl. Serv. Rep. Ser. 6.
DzuBin, A. 1969. Assessing breeding populations of ducks by ground counts. Pages 178230 in Saskatoon wetlands seminar. Can. Wildl. Serv. Rep. Ser. 6.

HaMmoND, M. C. 1969. Notes on conducting waterfowl breeding population surveys in the north central states. Pages 238-254 in Saskatoon Wetlands Seminar. Can. Wildl. Serv. Rep. Ser. 6.

Jessen, R. L., J. P. LiNdMeier, AND R. E. FARMes. 1964. A study of duck nesting and production as related to land use in Mahnomen County, Minnesota. Minnesota Dept. Conserv., Div. of Game and Fish Tech. Bull. 8( Sect. II) :26-85.

North Dakota State Water Commission. 1968. An inventory of water storage and retention structures in North Dakota. Pages 1-65 in Report, June, 1968.

Pospichal, G., E. Ferguson, A. E. Weinrich, J. S. Cromwell, T. Sechrist, and R. Balser. 1972. Waterfowl breeding pair survey for North and South Dakota. U.S. Bur. Sport Fish. Wildl., Minneapolis. 28pp. Processed.

Schroeder, C. H. 1971. Breeding ground survey in North Dakota in 1971. North Dakota State Game and Fish Dept. Job Rep. P-R Proj. W-67-R-11, Phase D, J-4. 8pp. Processed.

Stewart, R. E., AND H. A. Kantrud. 1971. Classification of natural ponds and lakes in the glaciated prairie region. U.S. Bur. Sport Fish. Wildl. Res. Pub. 92. 57pp.

$\longrightarrow$ AND 1972. Population estimates of breeding birds in North Dakota. Auk 89:766-788.

Stoudt, J. H. 1971. Ecological factors affecting waterfowl production in the Saskatchewan parklands. U.S. Bur. Sport Fish. Wildl. Res. Pub. 99. 58pp.

Accepted 26 September 1972. 